\title{
Urinary protein excretion rates in experimentally diabetic dogs and experimentally galactosaemic dogs
}

\author{
T.S. Kern and R. L. Engerman \\ Department of Ophthalmology, University of Wisconsin, Madison, Wisconsin, USA
}

\begin{abstract}
Summary. The relationship between urinary protein excretion and control of diabetes was evaluated in alloxan-diabetic dogs prospectively assigned to poor, moderate, or good glycaemic control. Protein excretion rate increased with the duration of insulin deficiency, and was significantly greater than normal in the poor control group by the fourth year of diabetes. Appreciable differences in the severity of the proteinuria were observed among animals of the poor and moderate glycaemic control groups; some of the animals excreted in excess of $500 \mathrm{mg}$ protein $/ 24 \mathrm{~h}$ while others excreted no more than normal throughout the 5 years of study. Differences in glycaemic control among these insulin-deficient animals seem not suffi-
\end{abstract}

cient to account for the observed differences in protein excretion. Immunoassay for albumin indicated that the defect resulting in supranormal protein excretion was at least partly glomerular in origin. Good glycaemic control prevented the protein loss from exceeding normal. A potential role of hyperglycaemia in the development of proteinuria was examined in nondiabetic dogs made experimentally hyperglycaemic with galactose. Consumption of a $30 \%$ galactose diet for up to 5 years duration had little influence on protein excretion.

Key words: Diabetes, galactosaemia, hyperglycaemia, proteinuria, dog, glycaemic control, polyol pathway.
The pathogenesis of increased urinary excretion of protein in diabetes is unclear. Abnormalities of kidney morphology, biochemistry and haemodynamics develop in diabetes, and each have been postulated as contributing to supranormal protein excretion [1-5]. The protein handling defect seems to occur chiefly in the glomerulus in diabetic patients; excretion of albumin is excessive, whereas the urinary concentration of proteins secreted by the renal tubules (such as betamicroglobulin) has been found to be normal by some investigators and abnormal by others $[1,6]$. The onset of heavy proteinuria carries a poor prognosis for diabetic patients; the average duration of survival without renal support therapy is only 7 years [7].

Diabetic dogs kept insulin-deficient for several years develop a renal disease that is morphologically similar to that seen in diabetic patients [8-10]. In the present report, the relationship between glycaemic control and the development of proteinuria was evaluated in alloxan-diabetic dogs, and a potential role of hyperglycaemia as a cause of the proteinuria was examined in experimentally galactosaemic dogs.

\section{Materials and methods}

Healthy adult dogs ( 1.5 to 2.5 years old) of either sex were randomly assigned to be made experimentally diabetic with alloxan or to remain as normal controls. Diabetic animals were prospectively assigned to poor, good or moderate glycaemic control. Animals in the poor glycaemic control group were given insufficient insulin so as to remain hyperglycaemic and glycosuric; whereas, those in good glycaemic control were given measured amounts of food and insulin twice daily, sufficient to minimise hyperglycaemia and glucosuria [11]. Glycaemic control in the moderate control group was intended to be intermediate between poor and good control, but both the moderate and poor glycaemic control groups were insulin-deficient. Experimental galactosaemia was induced in otherwise normal animals by feeding a diet enriched with $30 \%$ D-galactose [12]. Protein content of the unsupplemented diet was $26 \%$. All animals were housed in metabolism cages, and $24 \mathrm{~h}$ urine samples were collected for quantitation of protein. $\mathrm{HbA}_{1}$ was measured 2 to 4 times per year using mini-columns (Isolab, Inc., Akron, Ohio, USA) after incubation to remove labile adducts.

\section{Urinary protein}

To study the relationship between glycaemic control and protein excretion, urinary protein concentration for each animal was evaluated prior to the induction of diabetes (baseline), and throughout the first, fourth and fifth years of diabetes. The number of dogs in the diabetic groups (good, moderate and poor control) and normal group were $n=9,5,8$ and 9 , respectively. The effect of experimental galactosaemia $(n=5)$ on protein excretion was studied at similar durations. The concentration of protein excreted in urine was estimated semiquantitatively; urine that tested positive with Albustix (Ames, Elkhart, Indiana, USA) was mixed with sulfosalicylic acid (SSA), and the amount of turbidity that developed was compared visually with the turbidity in a 10-point standard curve covering the range of 0 to $100 \mathrm{mg}$ protein/dl [13]. Restricting the SSA assay only to Albustixpositive urines seemingly did not exclude lesser degrees of proteinuria which were below the claimed detection limits of Albustix ( $30 \mathrm{mg} / \mathrm{dl}$ ). For example, $24 \mathrm{~h}$ urine samples (from all groups) showing a positive reaction to Albustix, in fact, had no detectable protein $(<5 \mathrm{mg} / \mathrm{dl}$ ) by the more sensitive SSA method $62 \%( \pm 34 \%$ SD) of the tests during year 1 . Urine showing a negative or trace reaction to Albustix was 
considered to be protein-free, so the method likely underestimated microproteinuria. Protein excretion per day was calculated as the product of each day's protein concentration per $\mathrm{ml}$ (as estimated by the SSA method) and $24 \mathrm{~h}$ urine volume. Urine was tested for protein 22 to 52 times each year.

\section{Urinary albumin}

In a subsequent cross-sectional study of other animals, the extent to which glomerular abnormalities may account for the protein loss was studied using an immunochemical method that is specific for canine albumin. The radial immunodiffusion method and the method for total urinary protein (Bradford) to which it is compared are each more sensitive than the SSA test described above, and can detect microalbuminuria when present. The duration of insulin-deficient diabetes $(n=9 ; 3$ animals in poor glycaemic control and 6 in moderate glycaemic control) or galactosaemia $(n=12)$ in this cross-sectional survey ranged from 1 to 5 years.

Radial immunodiffusion (RID) plates were prepared by the method of Mancini et al. [14]. The antibody used (rabbit anti-dog albumin; cappel, Malvern, Penn, USA) was judged to be monospecific for canine albumin by immunoelectrophoresis and RID of dog plas$\mathrm{ma}$. The final dilution of antibody in the gel was $1: 80$. This concentration of antibody allowed quantitation of albumin in undiluted urine of normal dogs and of diabetic dogs that were not grossly proteinuric. Urine from moderate control diabetic dogs and poor control diabetic dogs were assayed also at a 1:10 dilution in order to quantitate albumin even in proteinuric animals. Sieves were used to prevent food or fecal matter from contaminating the urine during collection, and possible effects of such contamination on urinary albumin concentration were examined by incubating $1 \mathrm{~g}$ of crushed dog food or feces (from a dog in poor glycaemic control) in $10 \mathrm{ml}$ of normal urine $(7 \mathrm{~h}$ at $22^{\circ} \mathrm{C}$ ).

Urine or purified dog albumin standard (18ul) was added to the radial immunodiffusion wells in duplicate. The diameter (D) of the precipitin rings was measured after incubation for 3 days in a humid chamber. The squared diameter of the precipitin ring $\left(D^{2}\right)$ of the standards was plotted against protein concentration, and the albumin content of urine was derived from the standard curve. The excretion rates for albumin reported are the mean of two samples per animal taken 3 months apart. The radial immunodiffusion assay for canine albumin was linear over the range of $5-400 \mu \mathrm{g} / \mathrm{ml}$. Within-run coefficient of variation was $2.7 \%$, and between-run variation was $6.3 \%$ in the normal range and $14.4 \%$ in urine with heavy proteinuria $(1400 \mu \mathrm{g} / \mathrm{ml})$. Results were not affected by collection of urine in protease inhibitors [1 $\mathrm{g}$ EDTA plus $0.75 \mathrm{ml}$ apoprotinin (Sigma, St. Louis, Missouri, USA) plus $62 \mathrm{mg}$ phenylmethyl sulfonylfluoride], under mineral oil, nor in containers chilled to $4^{\circ} \mathrm{C}$.

A possible effect of non-enzymatic glycosylation on albumin immunoreactivity was evaluated after incubating aliquots of canine albumin (100 nmol, Sigma) in $20 \mathrm{mmol} / 1$ glucose or galactose $\left(37^{\circ} \mathrm{C}\right)$ under toluene for 11 days. The extent of non-enzymatic glycosylation of the albumin was measured by the fructosamine method [15]. Incubation of the albumin in vitro with glucose or galactose resulted in a 2-fold increase of albumin-bound fructosamine equivalents (47 and $50 \mu \mathrm{mol}$ fructosamine/ $\mathrm{g}$ albumin following incubation in glucose and galactose, respectively) compared to normal ( $20 \mu \mathrm{mol}$ fructosamine $/ \mathrm{g}$ albumin), which did not alter albumin's immunoreactivity in this assay.

Some of the animals reported in the prospective study of proteinuria have had kidney and retinal morphology reported previously [12, 19]. Animals in the cross-sectional study of albuminuria are still living and have not been reported on elsewhere.

Total urinary protein was measured with the Bradford dye-binding assay [16] for comparison to immunoreactive albumin excretion. Erythrocyte polyol (sorbitol) concentration was quantitated several times each year by enzyme assay in normal and diabetic animals [17]. The polyol in erythrocytes of the galactosaemic dogs (galactitol) was not detected by that method, and so was quantitated by gas chromatography [18]. Galactitol represented more than $95 \%$ of the reported

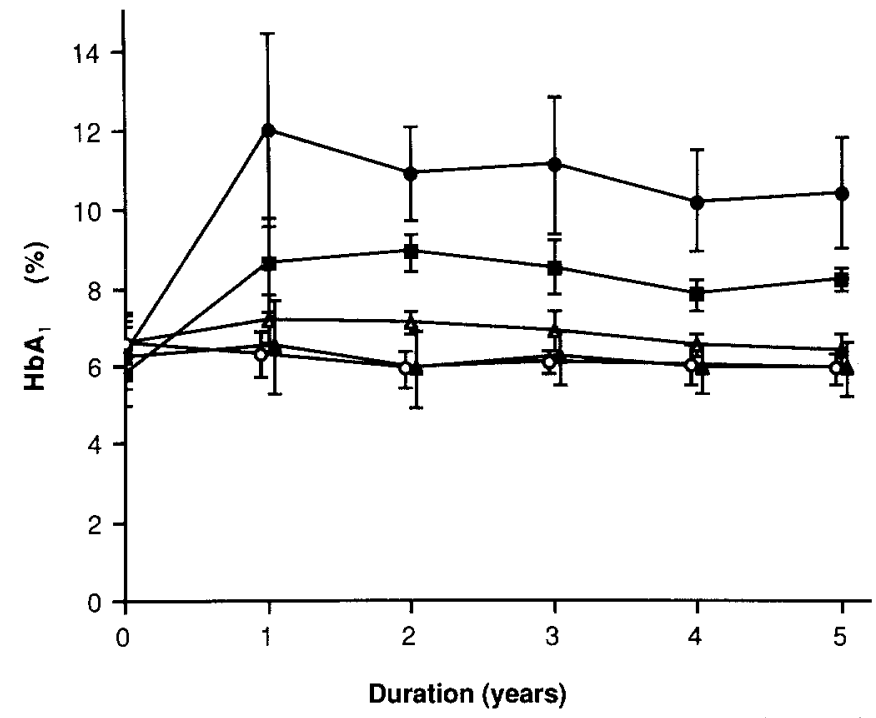

Fig. 1. Haemoglobin $A_{1}$ concentrations in alloxan diabetic dogs and experimentally galactosaemic dogs over the 5 years of study. Nor$\mathrm{mal}=\mathrm{O}$; good control diabetic $=\mathbf{\Lambda}$; moderate control diabetic $=\mathbf{\square}$; poor control diabetic $=\mathbf{0}$; galactosaemic $=\triangle$. (mean $\pm \mathrm{SEM})$

Table 1. Mean body weight and daily food consumption of diabetic dogs and galactose-fed dogs

\begin{tabular}{|c|c|c|c|}
\hline & \multicolumn{2}{|c|}{ Body weight ${ }^{\mathrm{a}}$} & \multirow{2}{*}{$\frac{\text { Food intake }}{\left(\mathrm{g} \cdot \mathrm{kg}^{-1} \cdot \text { day }^{-1}\right.}$} \\
\hline & $\mathrm{kg}$ & $\%$ of baseline & \\
\hline Normal & $12.5 \pm 1.7$ & $110 \pm 10$ & $18.7 \pm 2.7$ \\
\hline \multicolumn{4}{|l|}{ Diabetes } \\
\hline Good control & $13.9 \pm 2.0$ & $107 \pm 6$ & $18.0 \pm 3.1$ \\
\hline Moderate control & $13.2 \pm 2.5$ & $115 \pm 6$ & $21.8 \pm 2.5$ \\
\hline Poor control & $11.0 \pm 2.3$ & $99 \pm 12$ & $41.5 \pm 5.3$ \\
\hline Galactosaemia & $13.9 \pm 2.9$ & $124 \pm 6$ & $22.0 \pm 3.4$ \\
\hline
\end{tabular}

a at autopsy

polyol concentration in the galactosemic animals. Both analytical methods yielded similar results for erythrocyte sorbitol concentration in our hands.

\section{Statistical analysis}

Group comparisons were made by ANOVA with the Tukey-Kramer test after natural log transformation of data to reduce differences in group variances, and by non-parametric methods (Kruskal-Wallis test followed by Mann-Whitney U test). Additional tests included Student's t-test and non-parametric (Spearman; $r_{\mathrm{s}}$ ) correlation analysis. Correlation analysis by the parametric method (Pearson $r$; not shown) yielded similar conclusions.

\section{Results}

As expected, diabetic dogs in the poor and moderately glycaemic control groups were hyperglycaemic, glucosuric and polyuric and had stable $\mathrm{HbA}_{1}$ concentrations over the 5 years of study (Fig. 1). Mean $\mathrm{HbA}_{1}$ concentrations in the poor and moderately glycaemic control groups were significantly greater than the normal or diabetic dogs in good glycaemic control (all $p<0.01$ ). Animals in the good control group had values that were not significantly different from normal. $\mathrm{HbA}_{1}$ concen- 


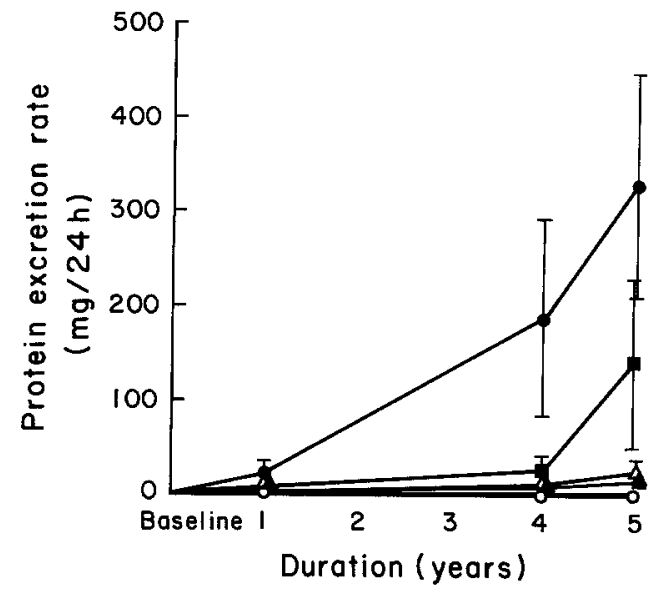

Fig. 2. Mean daily protein excretion in dogs as a function of glycaemic control and duration of diabetes or galactosaemia. Refer to Figure 1 for group identification key. Protein excretion was significantly greater than normal $(p>0.05)$ only in the poor control diabetic group during years 4 and 5 . Protein excretion in the poor control group was significantly greater also than that in good control diabetic dogs during the same time. (mean \pm SEM)

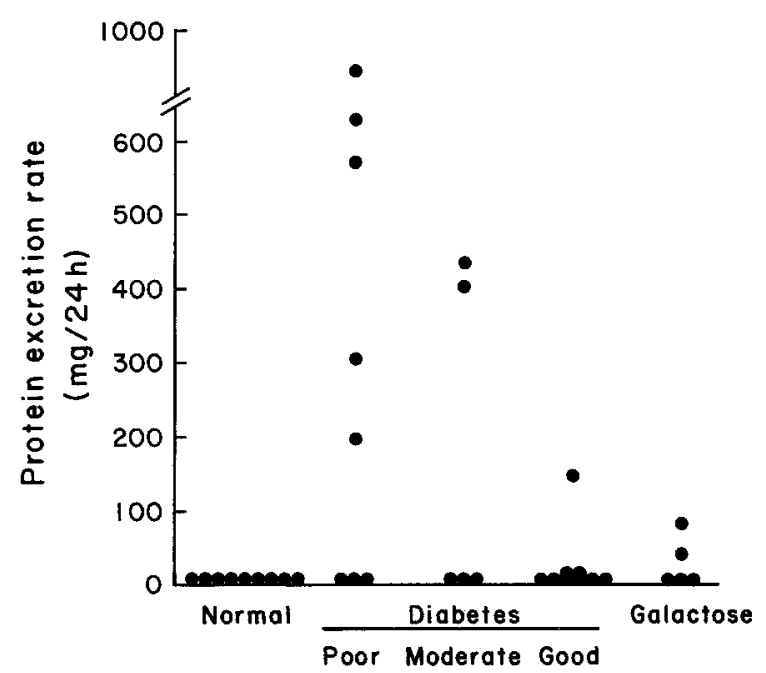

Fig. 3. Protein excretion rate in dogs during the 5 th year of alloxandiabetes or experimental galactosaemia. Appreciable differences in protein excretion are apparent among animals of the poor and moderate control diabetic groups. (This data was used to calculate group means for year 5 in Fig. 2)

trations in the galactosaemic group were significantly greater than normal $(p<0.05)$. The animals generally were healthy and not underweight (Table 1$)$.

\section{Protein excretion}

Daily protein excretion was similar in all groups prior to the study (baseline). Daily protein excretion in the poor and moderate glycaemic control groups tended to rise with increasing duration of diabetes, and was significantly greater than normal in the poor control group by the fourth year of diabetes ( $p<0.05$; Fig. 2 ). The rate of protein excretion during the fourth and fifth years of

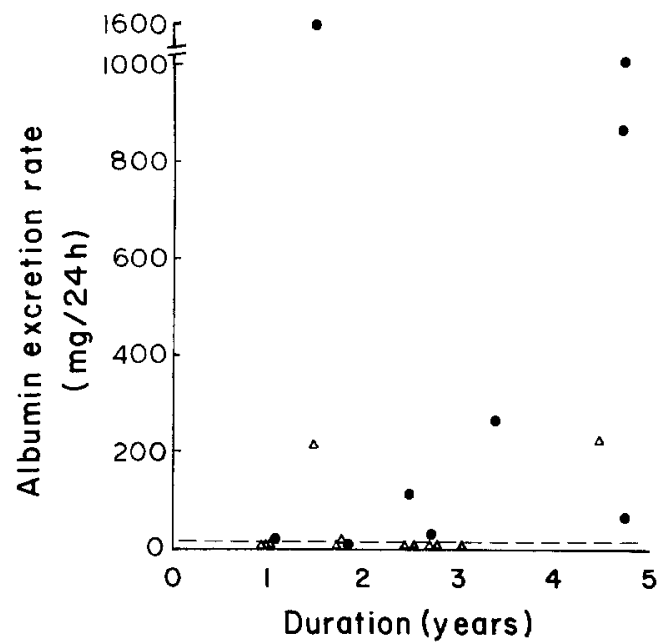

Fig. 4. Cross-sectional survey of albumin excretion in insulin-deficient diabetic dogs (moderate or poor glycaemic control; 9 ) and experimentally galactosaemic dogs $(\Delta)$. The upper limit of normal, 2 standard deviations above the mean of the normal group, is indicated by the broken line (- - ). Albumin excretion in the 7 animals comprising the normal group is $6.8 \pm 5.2 \mathrm{mg} /$ day (SD)

poor control diabetes was abnormal also when expressed relative to body weight. Although the protein excretion rate was significantly elevated in the poor glycaemic control group, appreciable differences existed among individual animals in that group with respect to the excretion rate; 3 of the 8 dogs in poor control for 5 years showed proteinuria in excess of $500 \mathrm{mg} / 24 \mathrm{~h}$, 2 showed "microproteinuria" (between 30 and $300 \mathrm{mg} / 24 \mathrm{~h}$ ), and 3 showed no increase in the protein excretion rate (Fig. 3). Mean $24 \mathrm{~h}$ protein excretion by these 8 animals was not correlated significantly with $\mathrm{HbA}_{1}$ concentration over the 5 year period $\left(r_{\mathrm{S}}=0.29\right)$, indicating that differences in glycaemic control between insulin-deficient animals were not sufficient to account for the differences in protein excretion. Some animals in moderate glycaemic control likewise failed to develop proteinuria during the 5 years of study. Although diabetic dogs in poor control were hyperphagic (Table 1), excessive consumption of food (or protein) was not significantly correlated with proteinuria in the insulin-deficient animals $\left(r_{\mathrm{S}}=0.29\right)$; some diabetic dogs that were not hyperphagic (moderate control) were proteinuric ( $>400 \mathrm{mg}$ protein/day); whereas, some diabetic dogs that were hyperphagic ( $>200 \%$ of normal food intake) excreted only normal amounts of protein. Good glycaemic control throughout the period of study significantly inhibited the loss of protein $(p<0.05$ compared to poor control in year 5) to a value that was not significantly different from normal.

Protein excretion by the experimentally galactosaemic dogs did not become significantly different from normal during the interval studied. Three of the 5 galactosaemic dogs showed no defect in protein excretion rate after 5 years of galactosaemia, and the other 2 galactosaemic dogs showed only a slight increase in protein excretion (Fig. 3). 


\section{Albumin excretion}

Sieves were judged to be successful in preventing contamination of urine with food or feces; the urine studied was not observed to have any evidence of such contaminants. Moreover, gross contamination of urine by food or fecal matter $(1 \mathrm{~g} / 10 \mathrm{ml})$ increased the amount of albumin detected in urine by a total of only $60 \mu \mathrm{g}$ or $110 \mu \mathrm{g}$, respectively.

Immunochemical study revealed that albumin excretion, like total protein excretion, was significantly greater than normal in dogs insulin-deficient for 2 to 5 years (moderate or poor control; $p<0.01$; Fig. 4 ). The immunochemical test for albumin seemed more sensitive than the SSA method and detected an elevation in albumin excretion ( $\geq 2 \mathrm{SD}$ above normal mean) in 5 animals judged to have normal protein excretion rates by the SSA method during the same interval. The amount of albumin excreted per $24 \mathrm{~h}$ was significantly correlated with the amount of total protein (Bradford assay) excreted during the same interval (normal plus diabetic animals; $r=0.84, p<0.01$ ).

Albumin excretion tended to be slightly greater than normal in the cross-sectional survey of galactosaemic dogs, a significant elevation being apparent by nonparametric tests but not by ANOVA. Nonetheless, albumin excretion exceeded the normal mean by more than 2 SD in only 3 of the 12 galactosaemic dogs. Albumin excretion in the galactose-fed animals was not significantly correlated with duration of galactosaemia.

Erythrocyte polyol concentration, used to estimate tissue polyol level, was significantly greater than normal $(37 \mathrm{nmol} / \mathrm{g} \mathrm{Hb} \pm \mathrm{SD}$ ) in the insulin-deficient dogs and the galactosaemic dogs $(83 \pm 30$ and $1446 \pm 489$ respectively; both $p<0.01$ ).

\section{Discussion}

Longstanding insulin deficiency leads to excessive excretion of protein in many dogs, as it does in many diabetic patients. The defect in protein excretion takes many months or years to develop in both diabetic patients and dogs, and is at least partly glomerular in origin, as judged from the supranormal loss of immunochemically identified albumin into the urine. Not all insulin-deficient dogs developed proteinuria during the 5 years of study. Appreciable differences in the amount of protein excreted were observed among insulin-deficient dogs, and differences in glycaemic control (as estimated by $\mathrm{HbA}_{1}$ concentration) were not sufficient to account for the observed differences in protein excretion among those insulin-deficient animals. It is not clear whether all insulin-deficient dogs would eventually develop proteinuria, or if like patients, only some (with yet unidentified characteristics) would develop the abnormality.

Proteinuria of $>0.5 \mathrm{gm} / 24 \mathrm{~h}$ in diabetic patients is believed to be one of the earliest indicators of a progres- sive decline in glomerular function leading, within a few years, to renal failure [1]. Protein may be excreted also at rates which, although below the usual clinical levels of detection, are of important prognostic significance [20]. The albumin excretion rate during this period of "microproteinuria" $(30-300 \mathrm{mg} / 24 \mathrm{~h})$ reportedly can predict the eventual progression to clinically significant proteinuria in diabetes. Inasmuch as good glycaemic control from the onset of diabetes inhibits the excessive loss of protein and abnormalities of renal morphology in rats and dogs [11, 21-25], these findings suggest that good glycaemic control might be expected to inhibit the development of diabetic nephropathy in patients if initiated early enough. Attempts to arrest or reverse early renal disease (microalbuminuria) with prolonged insulin therapy in patients seem to be successful $[26,27]$, but attempts to halt progression of overt nephropathy by improved glycaemic control have been unsuccessful [28, 29].

Experimental galactosaemia of up to 5 years duration is found to have only little influence on the excretion of protein or albumin. Kidneys from dogs galactosaemic for 5 years likewise have an almost normal appearance, in contrast to the marked nephropathy in insulin-deficient diabetic dogs. Kidney weight, mesangial volume, and the prevalence of obliterated glomeruli, glomerular exudates, and mesangial nodules in the galactosaemic dogs were comparable to those of normal animals and clearly are less than observed in poor control diabetic dogs [19]. Experimental galactosaemia, like diabetes, does nonetheless result in significant thickening of the basal lamina of glomerular capillaries [19] and diabetic-like retinopathy [12].

The cause of proteinuria in diabetic dogs is unclear. Alloxanised dogs kept in good glycaemic control remain free of the defect, indicating that the proteinuria in insulin-deficient animals is not due simply to nephrotoxicity from alloxan. Excessive consumption of protein (secondary to hyperphagia) is common in insulin-deficient animals, and high protein diets cause proteinuria in diabetic rats [30]. Hyperphagia alone, however, seems insufficient to account for the proteinuria in our diabetic dogs inasmuch as some hyperphagic diabetic animals lacked proteinuria or albuminuria, and other diabetic animals which were not hyperphagic had marked proteinuria. Morphologic abnormalities of glomeruli might play a role in the aetiology of the proteinuria. Although there was appreciable variability between glomeruli, kidneys from poor control diabetic dogs on the average had more histopathology (including nephromegaly, glomerular obliteration and mesangial expansion) than normal dogs or good control diabetic dogs. Not all poor control dogs, however, developed proteinuria over the same 5 year interval. Numerous other abnormalities of glomerular haemodynamics and permselectivity also are characteristic of diabetes, and the relative contributions of each to the proteinuria remain to be determined. 
Excessive activity of the polyol pathway has been implicated as a possible cause of increased protein excretion in diabetes; pharmacologic inhibition of the polyol pathway with an aldose reductase inhibitor (Sorbinil) has been claimed to inhibit microproteinuria in rats streptozotocin-diabetic for 2 months [31]. The present observations in dogs, however, suggest that polyol accumulation is not sufficient to account for the proteinuria in diabetes. Polyol concentrations in erythrocytes and other tissues (unpublished observations) are many-fold greater in galactosaemic dogs than in diabetic dogs, rats, or patients. Nonetheless, the incidence, prevalence and severity of proteinuria are less in galactosaemic dogs than in diabetic dogs. Study of the effects of Sorbinil on protein excretion and renal histopathology in experimentally galactosaemic dogs and diabetic dogs currently is underway in our laboratory.

Acknowledgements. We gratefully acknowledge the technical assistance of M.Larson, H. Wabers and M.Garment. This work was supported in part by PHS research grant EY-00300 from the National Eye Institute, and by a grant from the Juvenile Diabetes Foundation.

\section{References}

1. Viberti G, Keen $H$ (1984) The patterns of proteinuria in diabetes mellitus. Relevance to pathogenesis and prevention of diabetic nephropathy. Diabetes 33: 686-692

2. Hostetter TH, Rennke HG, Brenner BM (1982) The case for intrarenal hypertension in the initiation and progression of diabetic and other glomerulopathies. Am J Med 72: 375-383

3. Parving $\mathrm{H}-\mathrm{H}$, Viberti GC, Keen $\mathrm{H}$, Christiansen JS, Lassen NA (1983) Hemodynamic factors in the genesis of diabetic microangiopathy. Metabolism 32: 943-949

4. Mauer SM, Steffes MW, Goetz FC, Sutherland DER, Brown DM (1983) Diabetic nephropathy. A perspective. Diabetes 32 [Suppl 2]: $52-55$

5. Deckert T, Feldt-Rasmussen B, Mathiesen ER, Baker L (1984) Pathogenesis of incipient nephropathy: a hypothesis. Diabetic $\mathrm{Ne}-$ phropathy $3: 83-88$

6. Fletcher JA, Crockson RA, Mijovic C, Cooper EH, Bradwell AR, Barnet AH (1986) Low molecular weight proteinuria in insulindependent diabetes. Diabetes Res 3: 203-206

7. Andersen AR, Christiansen JS, Andersen JK, Kreiner S, Deckert T (1983) Diabetic nephropathy in Type I diabetes. Diabetologia 25: 496-501

8. Steffes MW, Mauer SM (1984) Diabetic glomerulopathy in man and experimental animal models. Int Rev Exp Pathol 26:147-175

9. Bloodworth JMB Jr, Engerman RL (1971) Spontaneous and induced diabetic microangiopathy. Acta Diabetol Lat 8 [Suppl 1]: 263-298

10. Brown DM, Andres GA, Hostetter TH, Mauer SM, Price R, Venkatachalam MA (1982) Kidney complications. Diabetes 31 [Suppl 1]: 71-81

11. Engerman R, Bloodworth JMB Jr, Nelson S (1977) Relationship of microvascular disease in diabetes to metabolic control. Diabetes 26: 760-769

12. Engerman RL, Kern TS (1984) Experimental galactosemia produces diabetic-like retinopathy. Diabetes 33:98-100

13. Hawk PB, Oser BL, Summerson WH (1947) Practical physiological chemistry, 13th edn. Blakeston, New York, pp 929-930

14. Mancini G, Carbonara AO, Heremans JF (1965) Immunochemi- cal quantitation of antigens by single radial immunodiffusion. Immunochemistry 2: 235-254

15. Johnson RN, Metcalf PA, Baker JR (1982) Fructosamine: a new approach to the estimation of serum glycosylprotein. An index of diabetic control. Clin Chim Acta 127:87-95

16. Bradford MM (1976) A rapid and sensitive method for the quantitation of microgram quantities of protein utilizing the principle of protein dye binding. Anal Biochem 72:248-254

17. Malone JI, Leavengood H, Peterson MJ, O'Brien MM, Page MG, Aldinger CE (1984) Red blood cell sorbitol as an indicator of polyol pathway activity: inhibition by sorbinil in insulin-dependent diabetic subjects. Diabetes 33: 45-49

18. Kern TS, Romang TC, Engerman RL (1986) Erythrocyte filterability in alloxan-diabetes and in experimental galactosemia. Clin Hemorheol 6: 395-404

19. Kern TS, Engerman RL (1987) Kidney morphology in experimental hyperglycemia. Diabetes 36: 244-249

20. Mogensen CE (1987) Microalbuminuria as a predictor of clinical diabetic nephropathy. Kidney Int 31: 673-689

21. Rasch R (1980) Prevention of diabetic glomerulopathy in streptozotocin diabetic rats by insulin treatment. Albumin excretion. Diabetologia 18: 413-416

22. Rasch R (1979) Prevention of diabetic glomerulopathy in streptozotocin diabetic rats by insulin treatment. Glomerular basement membrane thickness. Diabetologia 16: 319-324

23. Rasch R (1979) Prevention of diabetic glomerulopathy in streptozotocin diabetic rats by insulin treatment. Mesangial volume. Diabetologia 17: 243-248

24. Rasch R (1979) Prevention of diabetic glomerulopathy in streptozotocin diabetic rats by insulin treatment. Kidney size and glomerular volume. Diabetologia 16: 125-128

25. Kern TS, Engerman RL (1987) Effects of experimental hyperglycemia on kidney morphology. Diabetes 36 [Suppl 1]: $43 \mathrm{~A}$

26. Feldt-Rasmussen B, Mathiesen ER, Deckert T (1986) Effect of two years of strict metabolic control on progression of incipient nephropathy in insulin-dependent diabetes. Lancet II: 1300-1304

27. Bending JJ, Viberti GC, Bilous RW, Keen H, for the Kroc Collaborative Study Group (1985) Eight month correction of hyperglycemia in insulin-dependent diabetes mellitus is associated with a significant and sustained reduction of urinary albumin excretion rates in patients with microalbuminuria. Diabetes 34 [Suppl 3]: 69-73

28. Viberti GC, Bilous RW, Mackintoch B, Bending JJ, Keen H (1983) Long-term correction of hyperglycemia and progression of renal failure in insulin-dependent diabetes. Br Med J 286: 598-602

29. Tamborlane WV, Puklin JE, Bergman M, Verdonk C, Rudolf MC, Felig P, Genel M, Sherwin R (1982) Long-term improvement of metabolic control with the insulin pump does not reverse diabetic microangiopathy. Diabetes Care 5 [Suppl 1]: 58-64

30. Zatz R, Meyer TW, Rennke HG, Brenner BM (1985) Predominance of hemodynamic rather than metabolic factors in the pathogenesis of diabetic glomerulopathy. Proc Natl Acad Sci USA 82: $5963-5967$

31. Beyer-Mears A, Cruz E, Edelist T, Varagiannis E (1986) Diminished proteinuria in diabetes mellitus by Sorbinil, an aldose reductase inhibitor. Pharmacology 32: 52-60

Received: 2 March 1988

and in revised form: 8 August 1988

\section{Dr. T.S. Kern}

Department of Ophthalmology

University of Wisconsin

1300 University Avenue

Madison, Wisconsin 53706

USA 